Tersedia Online di http://journal2.um.ac.id/index.php/jmsp/

ISSN Online : 2541-4429

\title{
MANAJEMEN PROGRAM SCHOOL GARDEN GUNA MEWUJUDKAN SEKOLAH ADIWIYATA
}

\author{
Rakhmawati Indriani \\ E-mail: indrianirakhma@gmail.com \\ Universitas Negeri Malang, Jl. Semarang 5 Malang 65145
}

\begin{abstract}
The aims of this study are to describe the management of the School Garden program at senior high school, among others: the background; planning; implementation; evaluation; factors supporting and implementation of school garden programs as a form of Adiwiyata. Qualitative approach was used by case study design. Data were collected trough indepth interview, observation and documentation. The results of the application of the School Garden program can be seen from the achievements of the school after applying Adiwiyata program. The evaluation of the implementation of the School Garden program done directly, indirectly, and evaluation of the level-up which is expected to be used as benchmarks for principals and teachers in improving the management of the program. Implementation and management activities of the School Garden program is strongly influenced by the support and participation of all people in schools.
\end{abstract}

Keyword: special service management, school garden, adiwiyata school

\begin{abstract}
Abstrak: Penelitian ini bertujuan untuk mendiskripsikan manajemen program School Garden, antara lain: latar belakang; perencanaan; penerapan; evaluasi; faktor pendukung dan penghambat pelaksanaan program school garden di sekolah jenjang menengah atas sebagai wujud program adiwiyata. Penelitian ini menggunakan pendekatan kualitatif dengan rancangan studi kasus. Teknik pengumpulan data menggunakan wawancara mendalam, observasi, dan dokumentasi. Hasil penerapan program school garden dapat dilihat dari prestasi yang telah diraih sekolah. Evaluasi terhadap penerapan program school sarden dilakukan secara langsung, tidak langsung, dan evaluasi tingkat lanjut (follow-up). Kegiatan pelaksanaan dan pengelolaan program School garden sangat dipengaruhi oleh dukungan maupun partisipasi seluruh warga sekolah.
\end{abstract}

Kata kunci: manajemen layanan khusus, School Garden, sekolah adiwiyata.

Manusia merupakan bagian yang tidak dapat dipisahkan dari lingkungan hidupnya, sebaliknya lingkungan pun juga mempengaruhi manusia. Seiring dengan pertumbuhan penduduk yang semakin pesat dan meningkatnya kebutuhan hidup manusia, serta berkembangnya ilmu pengetahuan dan teknologi, telah mempercepat kerusakan lingkungan hidup sepertimeningkatnya pencemaran atau polusi. Oleh karena itu, untuk mengurangi kerusakan lingkungan perlu dilakukan pembinaan pada generasi penerus bangsa untuk sadar terhadap lingkungan.

Pada tanggal 3 Juni 2005, bertepatan dengan perayaan Pekan Lingkungan Hidup
Indonesia, bertempat di Jakarta Convention Center dilakukan penandatanganan Kesepakatan Bersama antara Menteri Negara Lingkungan Hidup dengan Menteri Pendidikan Nasional No. KEP-07/MENLH/06/2005 dan No. 05/VI/ $\mathrm{KB} / 2005$ tentang pembinaan dan pengembangan pendidikan lingkungan hidup. Kesepakatan ini merupakan permbaharuan dari kesepakatan terdahulu (21 Mei 1996, No. 0142/U/1996 dan KEP-89/MENLH/5/1996), diharapkan menjadi panduan yang baru bagi pelaksanaan seluruh kegiatan Pendidikan lingkungan hidup, baik yang dikoordinasikan oleh Kementerian Negara Lingkungan Hidup, maupun oleh Departemen 
Pendidikan Nasional serta pihak-pihak terkait lainnya.

Pendidikan lingkungan hidup merupakan salah satu dari program Adiwiyata yang dicanangkan oleh Kementerian Lingkungan Hidup. Pada sekolah Adiwiyata, pendidikan lingkungan hidup dijadikan sebagai muatan lokal. Menciptakan lingkungan yang bersih dan nyaman merupakan harapan setiap sekolah. Peserta didik beserta warga sekolah lainnya diharapkan mampu mengelola lingkungan sekolah dengan baik mulai dari proses perencanaan sampai dengan evaluasi. Lingkungan sekolah yang bersih, akan memberikan kenyamanan peserta didik untuk belajar dan termotivasi dalam mengikuti pembelajaran baik di dalam maupun di luar kelas. Manfaat tersebut bukan hanya diterima oleh peserta didik saja, tetapi juga semua warga sekolah.

Program School Garden ini diterapkan dengan memanfaatkan lahan sekolah yang tidak terlalu luas kemudian dijadikan sebagai tempat pelaksanaan program School Garden dan sebagai media pembelajaran peserta didik. Program School Garden ini merupakan kegiatan lingkungan berbasis partisipatif yang mengikutsertakan semua warga sekolah dalam mengelola lingkungan sekolah dan mendukung program tersebut. Setelah program tersebut diterapkan, diharapkan peserta didik dapat berperan serta dalam melestarikan lingkungan sekolah dengan tujuan peserta didik dapat mengikuti pembelajaran di sekolah dengan nyaman. Selain itu, diharapkan dengan program tersebut peserta didik dapat meningkatkan soft skill yang ada di dalam diri peserta didik melalui pembelajaran lingkungan hidup secara langsung di sekolah guna membangun kepribadian dan meningkatkan rasa peduli terhadap lingkungan. Sekolah tersebut mempunyai Tim Adiwiyata yang bertugas untuk membimbing siswa dalam mengelola lingkungan sekolah. Tim Adiwiyata ini terdiri dari beberapa guru dan petugas sekolah yang telah ditunjuk langsung untuk melaksanakan kegiatan dengan pelaksanaan program School Garden. Oleh karena itu, peneliti ingin meneliti bagaimana pengelolaan program School Garden mulai dari perencanaan, pelaksanaan, evaluasi, faktor pendukung dan penghambat dalam pengelolaan program School Garden di SMAN 7 Malang.
Program Adiwiyata bertujuan mewujudkan warga sekolah yang bertanggung jawab dalam upaya perlindungan dan pengelolaan lingkungan hidup melalui tata kelola sekolah yang baik untuk mendukung pembangunan berkelanjutan (Kementerian Lingkungan Hidup, 2011:3). Untuk mencapai tujuan program Adiwiyata, maka ditetapkan 4 (empat) komponen program yang menjadi satu kesatuan utuh dalam mencapai sekolah Adiwiyata (Kementerian Lingkungan Hidup, 2011:4). Keempat komponen tersebut adalah: kebijakan berwawasan lingkungan, pelaksanaan kurikulum berbasis lingkungan, kegiatan lingkungan berbasis partisipatif, serta pengelolaan sarana pendukung ramah lingkungan. Belajar dengan pendekatan lingkungan berarti peserta didik mendapatkan pemahaman dan kompetensi dengan cara mengamati dan melakukan secara langsung apa-apa yang ada dan berlangsung di lingkungan sekitar, baik di rumah maupun sekolah. Pembelajaran dengan pendekatan lingkungan pada hakekatnya mendekatkan dan memadukan peserta didik dengan lingkungannya, agar mereka memiliki rasa cinta, peduli, dan tanggung jawab terhadap lingkungannya. Inilah sebenarnya yang disebut life skill, sehingga pembelajaran membekali peserta didik dengan berbagai keterampilan untuk bisa hidup dan mempertahankan lingkungannya serta mengembangkan diri secara optimal (Mulyasa, 2006:205).

\section{METODE}

Penelitian ini menggunakan pendekatan kualitatif dengan jenis studi kasus pada satu objek penelitian yaitu manajemen program School Garden. Ulfatin (2013:48) menyatakan studi kasus sebagai metode penyelidikan secara langsung dengan latar yang alamiah dan memusatkan perhatian pada suatu peristiwa secara intensif dan rinci. Dari penjelasan di atas, pengertian penelitian studi kasus merupakan penelitian yang dilakukan secara menyeluruh dan mendalam pada satu subjek penelitian sehingga hasil yang diperoleh benar-benar rinci dan sesuai dengan fakta yang ada di lapangan. Peneliti menggunakan jenis desain studi kasus deskriptif, karena fokus penelitian hanya pada satu lokasi yang akan diteliti secara menyeluruh dan mendalam terhadap fenomena atau kasus 
yang diteliti, yaitu mengenai manajemen program School Garden di SMAN 7 Malang.

Penelitian kualitatif ini dilaksanakan di SMAN 7 Malang Jalan Cengger Ayam I/14 Malang. Peneliti memilih lokasi penelitian ini dikarenakan sekolah ini telah meraih beberapa penghargaan khususnya di bidang lingkungan hidup. Sumber data penelitian ini adalah informasi yang disampaikan oleh subjek penelitian pada saat penelitian, tindakan yang dilakukan oleh subjek penelitian, dan dokumen yang berkaitan dengan manajemen program School Garden. Langkah selanjutnya adalah analisis data yaitu suatu proses menyusun data agar bisa ditafsirkan dan disimpulkan. Wiyono (2007:93) menjelaskan tiga langkah Miles \& Huberman dalam proses analisis data, yaitu reduksi data, display data, dan verifikasi data. Reduksi data merupakan kegiatan memilih data yang tepat. Data yang masuk baik dari hasil catatan aktual di lapangan, hasil wawancara, hasil rekaman, ringkasan data, atau hasil data lainnya perlu direduksi sesuai dengan pertanyaan-pertanyaan penelitian dan kasuskasus yang ada. Langkah selanjutnya adalah display data/penyajian data. Proses penelitian meliputi beberapa tahapan yaitu tahap persiapan penelitian, tahap pelaksanaan penelitian, dan tahap penyusunan laporan penelitian.

\section{HASIL DAN PEMBAHASAN}

\section{Latar Belakang Diadakannya Program School Garden}

SMAN 7 Malang memulai untuk mengikuti program adiwiyata pada tahun 2010 dan meraih prestasi sebagai sekolah Adiwiyata di tingkat Kota. Tahun 2013, sekolah ini telah berhasil mencapai pada tingkat Adiwiyata Nasional dan tahun ini sekolah sedang berproses untuk menuju sekolah Adiwiyata Mandiri. SMAN 7 Malang mendapat penghargaan tersebut karena sekolah mampu melaksanakan kebijakan sekolah dan kebijakan pemerintah daerah untuk peduli terhadap lingkungan. Tujuan dilaksanakannya program School Garden di SMAN 7 Malang, pertama adalah memanfaatkan lahan sempit sekolah. Kedua, menanamkan kecintaan terhadap sayuran kepada semua warga sekolah sehingga mereka menyukai sayur. Ketiga, menambah nilai ekonomis pada hasil penjualan dari Pokja sayuran. Hasil penjualan sayuran pada Pokja
Sayur Organik, Pokja Hidroponik, Pokja Jamur, dan Pokja Pembibitan nantinya digunakan untuk pembelian bibit. Program School Garden di SMAN 7 Malang ini diadakan untuk membentuk kepribadian peserta didik agar memiliki kepedulian terhadap lingkungan sekitar baik di sekolah maupun di luar sekolah dan membantu peserta didik yang kurang mampu dari hasil penjualan Pokja Ekowirausaha. Program School Garden yang diterapkan di SMAN 7 Malang ini, diharapkan dapat memberikan dampak positif khususnya bagi peserta didik maupun warga sekolah lainnya. Melalui pembelajaran School Garden ini, dapat digunakan sebagai bekal/ menambah keterampilan bagi siswa. Jadi siswa tidak hanya diajari teori di kelas, tapi juga praktek secara langsung.

Sesuai dengan pendapat Kementerian Lingkungan Hidup (2013:1), yang menyatakan bahwa dalam rangka pengembangan pendidikan lingkungan hidup, sejak 2006 Kementerian Lingkungan Hidup (KLH) bersama dengan Kementerian Pendidikan dan Kebudayaan mengembangkan program Sekolah Peduli dan Berbudaya Lingkungan yang dikenal dengan Program Adiwiyata. Program ini dikembangkan secara berjenjang mulai dari tingkat Kabupaten, Provinsi, Nasional, dan Mandiri.

Sekolah memerlukan suatu manajemen layanan khusus yang dapat mengatur segala kebutuhan peserta didiknya sehingga tujuan pendidikan tersebut dapat tercapai. Oleh karena itu, dengan diterapkannya Program School Garden sebagai salah satu bagian dari manajemen layanan khusus bidang ekstrakurikuler di SMAN 7 Malang ini dapat dijadikan media pembelajaran bagi peserta didik baik di lingkungan sekolah maupun di rumah untuk lebih mencintai lingkungan, mulai dari kegiatan menanam, merawat, memanen, dan menjual. Dengan pembelajaran School Garden ini, dapat digunakan sebagai bekal/menambah keterampilan bagi siswa. Jadi siswa tidak hanya diajari teori di kelas, tapi juga praktek secara langsung. Sebagaimana pendapat Zulkarnain (2016) bahwa ekstrakurikuler perlu dikelola profesional agar bisa memberikan nilai tambahan bagi peserta didik dan dapat menjadi barometer perkembangan atau kemajuan sekolah yang seringkali diamati oleh wali murid maupun masyarakat. Selain itu, menurut Septiani \& Wiyono (2012) kegiatan ekstrakurikuler juga 
merupakan salah satu unsur penting dalam membangun kepribadian siswa. Sehingga profil kepribadian yang matang merupakan tujuan utama dalam kegiatan ekstrakurikuler.

\section{Perencanaan Program School Garden di SMAN 7 Malang}

Perencanaan program School Garden di SMAN 7 Malang ini dilakukan dengan membentuk koordinator program Adiwiyata berdasarkan surat keputusan (SK) Kepala Sekolah seperti yang telah tergambar pada struktur organisasi Adiwiyata SMAN 7 Malang yang bertugas untuk membina peserta didik dan warga sekolah lainnya dalam penerapan program School Garden. Alokasi anggaran yang digunakan dalam merencanakan kegiatan terkait Program School Garden di SMAN 7 Malang diperoleh dari RAKS SMAN 7 Malang sebesar $20 \%$. Melakukan perubahan kebijakan pada visi dan misi sekolah untuk menciptakan sekolah Adiwiyata. Tim dibagi ke dalam kelompok kerja (Pokja) mulai dari Pokja Pembibitan, Sayur Organik, Hidroponik, Jamur, dan lain sebagainya yang telah ditunjuk oleh Kepala Sekolah. Penyusunan program kerja atau kegiatan yang akan dilakukan oleh sekolah melalui persetujuan kepala sekolah dengan semua pihak yang terlibat di dalamnya. Pengorganisasian program School Garden sudah tertera dalam struktur organisasi yang telah dibentuk oleh Kepala Sekolah beserta koordinator masing-masing Pokja yang terdiri dari beberapa guru yang telah dipilih oleh Kepala Sekolah guna mendukung dan mewujudkan program sekolah tersebut. Kebijakan sekolah untuk melakukan sosialisasi Program School Garden sebagai wujud dari Program Adiwiyata yang ditujukan kepada semua warga sekolah di SMAN 7 Malang dilakukan dengan mengikuti pelatihan-pelatihan dengan pihak terkait, seminar/ workshop, rapat guru, maupun rapat dengan orangtua. Beberapa guru yang terpilih untuk menjadi Tim Adiwiyata berkesempatan untuk mengikuti kegiatan sosialisasi berupa pelatihanpelatihan, workshop, ataupun seminar yang diadakan oleh sekolah, Dinas Pendidikan Kota Malang, Badan Lingkungan Hidup (BLH) Kota maupun Provinsi, TOT (Training of Trainers) Ecomapping dengan GIZ/PAKLIM maupun lembaga lainnya dengan tujuan memberikan pemahaman kepada sumber daya manusia yang ada dan meningkatkan sumber daya manusia di bidang lingkungan hidup terkait Program Adiwiyata. Peserta didik juga mengikuti kegiatan sosialisasi mengenai program Adiwiyata yang diterapkan di sekolah dengan cara berpartisipasi dalam penyuluhan yang dilakukan oleh sekolah pada saat PPDB (Penerimaan Peserta Didik Baru) dan penyuluhan yang diselenggarakan oleh BPTP (Balai Pengkajian Teknologi Pertanian) dengan tujuan untuk menambah wawasan dan pengetahuan kepada mereka mengenai pentingnya materi sosialisasi tersebut.

Sebagaimana penjelasan Ningtyas (2013), dari hasil penelitian tersebut peneliti dapat menyimpulkan bahwa manajemen lingkungan sekolah dibuat agar peserta didik sebagai generasi penerus bangsa di masa mendatang memiliki pengetahuan, menciptakan rasa tanggung jawab dan peduli terhadap lingkungan baik di sekolah maupun di luar sekolah. Pada pengelolaannya, perlu adanya campur tangan dari berbagai pihak mulai dari peserta didik, pendidik, dan semua warga sekolah sampai pihak luar sekolah yang mendukung terselenggaranya program Adiwiyata.

Pengorganisasian program School Garden sangat berpengaruh terhadap keberlangsungan program/kegiatan Adiwiyata yang telah direncanakan sebelumnya guna mencapai tujuan yang diinginkan secara efektif dan efisien. Pengorganisasian dilakukan dengan membagi tugas pada tiap koordinator Kelompok Kerja (Pokja) dan pemberian pengarahan program Adiwiyata dari Kepala Sekolah, mengintegrasikan kurikulum berbasis lingkungan hidup pada semua mata pelajaran dan pendidikan lingkungan hidup (muatan lokal), kegiatan sosialisasi atau pelatihan diikuti oleh Tim Adiwiyata beserta warga sekolah lainnya dari Dinas setempat/pihak luar sekolah terkait program Adiwiyata yang akan dilaksanakan di sekolah.

\section{Pelaksanaan Program School Garden di SMAN 7 Malang}

Kegiatan yang dilakukan pada saat pelaksanaan program School Garden di SMAN 7 Malang meliputi: memelihara dan merawat lingkungan hidup yang terencana (kegiatan piket kelas dilakukan setiap selesai pelajaran), 
memanfaatkan lahan dan fasilitas sekolah sesuai pengelolaan lingkungan hidup (penanaman TOGA), mengembangkan kegiatan ko-kurikuler yang sesuai dengan upaya perlindungan dan pengelolaan lingkungan hidup (Kegiatan Jumat Bersih). Lingkungan sekolah yang bersih dan sehat diharapkan semua warga sekolah sadar akan pentingnya hidup bersih dan sehat dan mendukung terlaksananya Program School Garden di SMAN 7 Malang. Mengembangkan materi lingkungan hidup yang diintegrasikan ke dalam pembelajaran, pendidikan lingkungan hidup (PLH) sebagai muatan lokal (mulok) dan melalui program School Garden ini diharapkan akan membentuk kepribadian peserta didik menjadi lebih baik dan menjadi pribadi yang memiliki kepedulian terhadap lingkungan sekitarnya.

Pelaksanaan program School Garden diantaranya seperti kegiatan ko-kurikuler di SMAN 7 Malang antara lain kegiatan Jumat Bersih dan pelaksanaan kegiatan pada PokjaPokja (Kelompok Kerja) yang telah dibentuk oleh Tim Adiwiyata. SMAN 7 Malang mendapatkan bantuan dari pihak luar sekolah seperti BPTP (Balai Pengkajian Teknologi Pertanian) berupa bibit tanaman sayuran organik dan lain sebagainya. Perawatan dan pemeliharaan di dalam kegiatan School Garden dilakukan setiap hari baik oleh petugas kebersihan, perawatan juga dilakukan oleh peserta didik namun di luar jam pelajaran atau di luar kegiatan belajar mengajar (KBM).

Pendidikan lingkungan hidup yang dilaksanakan di sekolah merupakan salah satu syarat dalam mengikuti Program Adiwiyata. Pendidikan lingkungan hidup yang diintegrasikan ke dalam pembelajaran dan melalui program School Garden ini diharapkan akan membentuk kepribadian peserta didik menjadi lebih baik dan menjadi pribadi yang memiliki kepedulian terhadap lingkungan sekitarnya. Dalam menciptakan lingkungan sekolah yang bersih dan sehat diharapkan semua warga sekolah sadar akan pentingnya hidup bersih dan sehat dan mendukung terlaksananya Program School Garden di SMAN 7 Malang. Pendidikan lingkungan hidup (PLH) yang diintegrasikan ke dalam pembelajaran dan melalui program School Garden ini diharapkan akan membentuk kepribadian peserta didik menjadi lebih baik dan menjadi pribadi yang memiliki kepedulian terhadap lingkungan sekitarnya. Pelaksanaan program School Garden diantaranya seperti kegiatan kokurikuler di SMAN 7 Malang antara lain kegiatan Jumat Bersih dan pelaksanaan kegiatan pada Pokja-Pokja (Kelompok Kerja) yang telah dibentuk oleh Tim Adiwiyata.

Seperti penjelasan Rismawati (2013), dari hasil penelitian tersebut peneliti dapat menyimpulkan bahwa dengan adanya program sekolah peduli dan berbudaya lingkungan maka akan memberikan perubahan pada sekolah dalam meningkatkan kualitas lembaga pendidikan, namun dalam pengelolaannya banyak hambatan yang terjadi dan perlu adanya dukungan dari seluruh warga sekolah guna mengoptimalkan terselenggaranya program tersebut di sekolah. Pada pelaksanaan program School Garden ini banyak sekali pihak yang berperan mendukung pelaksanaan kegiatan baik pihak sekolah maupun pihak luar sekolah guna mewujudkan sekolah yang bersih dan sehat. Pemanfaatan fasilitas sekolah yang ada (lingkungan sekolah) sebagai sarana pendukung ramah lingkungan dan sumber belajar berbasis lingkungan bagi peserta didik maupun warga sekolah lainnya.

\section{Evaluasi terhadap Pelaksanaan program School Garden di SMAN 7 Malang}

Evaluasi terhadap program School Garden dilakukan untuk melihat seberapa tingkat ketercapaian kegiatan yang telah dilaksanakan dibandingkan dengan rencana yang telah ditetapkan sebelumnya. Hasil evaluasi terhadap Program School Garden dapat dijadikan tolok ukur bagi kepala sekolah dan guru-guru dalam meningkatkan pelaksanaan program tersebut. Evaluasi secara langsung dilakukan jika pada masing-masing Kelompok Kerja (Pokja) terdapat kendala dalam pelaksanaannya, seperti tempat yang digunakan untuk budidaya jamur tiram dimakan rayap karena terbuat dari bambu, maka perlu dilakukan pembaharuan tempat budidaya yang sebelumnya perlu direncanakan terlebih dahulu bagaimana membuat tempat budidaya yang tepat bagi Pokja jamur tiram tersebut. Evaluasi secara tidak langsung adalah dengan mengisi jurnal kegiatan tiap kelompok kerja (pokja) yang nantinya akan dijadikan sebagai laporan perkembangan oleh masing-masing 
Pokja yang telah dibentuk.

Evaluasi terhadap pelaksanaan program School Garden di SMAN 7 Malang dilakukan setiap 3 bulan sekali, dikarenakan masa tumbuh sayur sekitar 3 minggu, minggu awal biasanya untuk penggemburan. Dalam 3 bulan itu, sayur sudah bisa dipanen sebanyak 3-4 kali. Evaluasi dilakukan dengan melihat kondisi tanah, pupuk, dan sebagainya. Tidak hanya Tim Adiwiyata saja yang melakukan evaluasi, evaluasi juga dilakukan oleh pihak BPTP yakni Ir. Hari selaku pembina dan pembimbing Tim Adiwiyata beserta warga sekolah lainnya dalam pelaksanaan program School Garden di SMAN 7 Malang.

Seperti penjelasan Kurniadi dan Machali (2012:131)yang menyatakan bahwa "pengawasan (controlling) adalah proses pengamatan dan pengukuran suatu kegiatan operasional dan hasil yang dicapai dibandingkan dengan standar yang telah ditetapkan sebelumnya yang terlihat dalam rencana". Hal yang sama juga diutarakan oleh Darmawan (2011:56), yang menyatakan bahwa "pengawasan sangat erat kaitannya dengan perencanaan, bahkan dapat dikatakan melalui perencanaanlah kita dapat menjernihkan kesan atau konotasi negatif mengenai pengawasan". Oleh karena itu, evaluasi terhadap pelaksanaan program School Garden sangat penting dilakukan guna membandingkan tingkat ketercapaian antara program/kegiatan yang telah dilaksanakan dengan perencanaan kegiatan yang telah direncanakan sebelumnya. Evaluasi dapat dilakukan dengan melakukan pemantauan dan melihat laporan perkembangan kegiatan dalam pelaksanaan program School Garden yang nantinya dapat dijadikan sebagai tolok ukur bagi Kepala Sekolah maupun Tim Adiwiyata dalam meningkatkan tingkat keberhasilan pelaksanaaan program tersebut di sekolah.

\section{Faktor Pendukung dan Penghambat dalam Pelaksanaan Program School Garden}

Faktor pendukung dari dalam dalam pelaksanaan program School Garden adalah: (1) sumber daya manusia yang terdidik (mayoritas dari pendidik sudah berpendidikan sarjana, kesadaran terhadap lingkungan cukup tinggi), (2) fasilitas sekolah yang memadai, (3) adanya kerjasama yang baik diantara semua warga sekolah dan juga pihak luar sekolah atau lembaga lain yang bersedia membantu sekolah dalam menyelenggarakan Program School Garden tersebut. Sedangkan faktor pendukung dari luar sekolah (faktor ekstern) meliputi: (1) Unit Pelaksana Teknis Daerah (Dinas Pertanian, Dinas Kesehatan, Dinas Perikanan, Dinas Kebersihan dan Pertamanan dan Perguruan Tinggi), (2) Komite Sekolah, (3) Tokoh Masyarakat, dan (4) Kerjasama dengan pihak USAID dan GIZ/ PAKLIM.

Faktor penghambat dalam pelaksanaan program School Garden adalah terdapat beberapa peserta didik yang tidak mau ikut berpartisipasi dalam kegiatan Pokja-Pokja yang sudah dibentuk dan kegiatan Jumat Bersih, maka diperlukan bimbingan dari Tim Adiwiyata dan juga Pembina dari masing-masing Pokja agar peserta didik tersebut termotivasi untuk ikut terjun langsung dalam kegiatan Program School Garden tersebut. Kendala lain dalam pelaksanaan program School Garden terkait program Adiwiyata di SMAN 7 Malang yaitu pada saat Penerimaan Peserta Didik Baru (PPDB) dan adanya kenaikan kelas, sekolah (Tim Adiwiyata) harus mensosialisasikan program Adiwiyata yang diterapkan di SMAN 7 Malang kepada peserta didik baru, agar mereka antusias untuk ikut berpartisipasi dalam kegiatan-kegiatan program Adiwiyata yang telah dibagi dalam beberapa Pokja, dan peserta didik bebas untuk memilih Pokja mana yang akan mereka ikuti. Sekolah harus menyesuaikan lagi dengan peserta didik baru dan memulainya dari awal. Sekolah juga masih berproses untuk mempersiapkan menjadi Sekolah Adiwiyata Mandiri dan harus melakukan binaan kepada 12 sekolah imbas yang terdapat di Kota Malang.

Kesimpulan faktor pendukung baik dari luar maupun dari dalam sangat berpengaruh terhadap terlaksananya program Adiwiyata di sekolah. Seperti penjelasan Lusty (2013), bahwa peran warga sekolah dalam penyelenggaraan pendidikan lingkungan hidup seperti peran kepala sekolah, guru, siswa, dan pihak terkait lainnya sangat berdampak terhadap kualitas lembaga pendidikan, namun dalam penerapannya pasti terdapat kendala yang dihadapi oleh sekolah di samping adanya dukungan dari berbagai pihak dalam penyelenggaraan pendidikan lingkungan hidup tersebut. Dalam pelaksanaan program School Garden di SMAN 7 Malang, di samping 
ada dukungan dari dalam sekolah dan pihak luar sekolah, namun masih terdapat kendala atau hambatan dalam pelaksanaannya. Jika pelaksanaan program School Garden ini bisa dikatakan berhasil, maka pengelolaan programnya perlu dipertahankan dan ditingkatkan lagi menjadi lebih baik. Namun, jika masih banyak kendala yang ditemui pada saat pelaksanaan program School Garden ini, maka hambatan atau kendala yang ada harus segera diperbaiki dan diminimalkan guna mencapai tujuan yang diinginkan.

\section{KESIMPULAN DAN SARAN}

\section{Kesimpulan}

Berdasarkan hasil analisis data tersebut, diperoleh lima simpulan hasil penelitian sebagai berikut. Pertama, program School Garden di SMAN 7 Malang ini diadakan untuk membentuk kepribadian peserta didik agar memiliki kepedulian terhadap lingkungan sekitar baik di sekolah maupun di luar sekolah dan membantu peserta didik yang kurang mampu dari hasil penjualan Pokja Ekowirausaha. Kedua, perencanaan program School Garden di SMAN 7 Malang dilakukan dengan membentuk koordinator program Adiwiyata yang bertugas untuk membina peserta didik dan warga sekolah lainnya dalam penerapan program School Garden. Ketiga, penerapan program School Garden di SMAN 7 Malang telah berjalan dengan baik. Hasil penerapan program School Garden dapat dilihat dari prestasi yang telah diraih sekolah setelah menerapkan program Adiwiyata. Kegiatan yang dilakukan pada saat pelaksanaan program School Garden di SMAN 7 Malang meliputi: Implementasi kebijakan sekolah berwawasan lingkungan, pengembangan kurikulum dan pembelajaran berbasis lingkungan, pengembangan kegiatan berbasis partisipatif, pengelolaan sarana pendukung sekolah yang ramah lingkungan.

Keempat, evaluasi terhadap penerapan program School Garden di SMAN 7 Malang dilakukan secara langsung, tidak langsung, dan evaluasi tingkat lanjut (follow-up) yang nantinya diharapkan dapat dijadikan tolok ukur bagi kepala sekolah dan guru-guru dalam meningkatkan pengelolaan program tersebut. Kelima, kegiatan pelaksanaan dan pengelolaan program School
Garden sangat dipengaruhi oleh dukungan maupun partisipasi seluruh warga sekolah, tanpa dukungan mereka maka program School Garden tidak dapat berjalan dengan baik maksimal. Namun, selain faktor pendukung juga terdapat faktor penghambat yang harus diminimalisir sekolah yakni berasal dari diri peserta didik yang cenderung malas berpartisipasi dalam dalam pelaksanaan program School Garden.

\section{Saran}

Dari penelitian ini, saran-saran yang diajukan yaitu (1) Bagi Kepala Dinas Pendidikan Kota Malang, diharapkan mampu membentuk peserta didik yang berkarakter mencintai lingkungan, membina kebersamaan antar peserta didik dan menciptakan generasi yang mampu berwirausaha; (2) Bagi Kepala SMAN 7 Malang, hendaknya dapat dijadikan sebagai bahan rujukan bagi kepala sekolah untuk meningkatkan pengelolaan program School Garden terkait kegiatan Adiwiyata yang telah diterapkan di SMAN 7 Malang dengan cara membimbing seluruh warga sekolah dalam pelaksanaan program School Garden melalui pembiasaan kegiatan Jumat Bersih; (3) Bagi Guru SMAN 7 Malang, hendaknya guru dapat menjalankan secara seimbang antara tugas mengajar dan tugas sebagai anggota Tim Adiwiyata dalam menjalin kerjasama dengan warga sekolah mupun pihak luar sekolah agar kegiatan Adiwiyata tetap terlaksana dengan baik; (4) Bagi Orangtua/Wali Murid SMAN 7 Malang, diharapkan dapat mendukung dan tetap melaksanakan kegiatan program Adiwiyata yang sudah diterapkan di SMAN 7 Malang dengan cara ikut menjaga kebersihan di sekitar lingkungan sekolah maupun di rumah; (5) Bagi Jurusan Administrasi Pendidikan, diharapkan dapat dijadikan untuk menambah rujukan (referensi) yang telah ada dengan perkembangan yang terjadi terkait manajemen layanan khusus; (6) Bagi Mahasiswa Administrasi Pendidikan, hasil penelitian ini dapat dimanfaatkan sebagai tambahan referensi tentang manajemen layanan khusus; (7) Bagi Peneliti lain, diharapkan dapat memanfaatkan hasil penelitian dengan sebaikbaiknya, juga dapat digunakan sebagai bahan rujukan atau referensi dalam penelitian sejenis serta mengembangkannya lebih mendalam. 


\section{DAFTAR RUJUKAN}

Kementerian Lingkungan Hidup Republik Indonesia. 2013. Penghargaan Sekolah Adiwiyata Nasional 2013, (Online), (http://www.menlh.go.id/ penghargaan-sekolah-adiwiyata-nasional-2013/), diakses 21 Februari 2014.

Kementerian Negara Lingkungan Hidup. 2011. Sekolah Peduli dan Berbudaya Lingkungan. Jakarta: Deputi Bidang Komunikasi.

Kurniadi, D. \& Machali, I. 2012. Manajemen Pendidikan: Konsep dan Prinsip Pengelolaan Pendidikan. Jogjakarta: Ar-Ruzz Media.

Lusty, K. C. 2013. Peran Warga Sekolah dalam Penerapan Pendidikan Lingkungan Hidup di SDN Dinoyo 2 Malang. Skripsi tidak diterbitkan. Malang: Fakultas Ilmu Pendidikan. Universitas Negeri Malang.

Mulyasa, E. 2006. Implementasi Kurikulum 2004: Panduan Pembelajaran KBK. Bandung: PT Remaja Rosdakarya.

Ningtyas, L. 2013. Manajemen Lingkungan Sekolah Pemenang UKS dan Adiwiyata Nasional (Studi Kasus di SDN Tunjungsekar I Malang. Skripsi tidak diterbitkan. Malang: Fakultas Ilmu Pendidikan. Universitas Negeri Malang.

Rismawati, T. 2013. Efektivitas Program Adiwiyata sebagai Upaya Penanaman Rasa Cinta Lingkungan di SMPN 3 Malang. Skripsi tidak diterbitkan. Malang: Fakultas Ilmu Sosial. Universitas Negeri Malang.

Septiani, I. \& Wiyono, B.B. 2012. Manajemen Kegiatan Ekstrakurikuler dalam Meningkatkan Kualitas Sekolah. Jurnal Manajemen Pendidikan, 23 (5): 424-433.

Ulfatin, N. 2013. Metode Penelitian Kualitatif di Bidang Pendidikan: Teori dan Aplikasinya. Malang: Bayumedia Publishing.

Wiyono, B. B. 2007. Metodologi Penelitian (Pendekatan Kuantitatif, Kualitatif, dan Action Research (Burhanuddin, Ed.). Malang: Fakultas Ilmu Pendidikan Universitas Negeri Malang.

Zulkarnain, W. 2016. Layanan Khusus Peserta Didik Sebagai Penguat Manajemen Pendidikan. Prosiding Seminar Nasional Penguatan Manajemen Pendidikan di Era Kompetisi Global. http://anzwild.com/layanan-khusus-pesertadidik-sebagai-penguat-manajemen-pendidikan. Diakses 9 September 2017. 